\title{
EDIBLE INSECTS AS A SOURCE OF ALTERNATIVE PROTEIN. A REVIEW
}

\author{
Nataliya A. Gorbunova, ${ }^{\star}$ Alexander N. Zakharov \\ V. M. Gorbatov Federal Research Center for Food Systems of Russian Academy of Sciences, Moscow, Russia
}

Keywords: food resource, entomophagy, environmental protection, public perception, non-animal protein, meat alternatives

\begin{abstract}
The current state and research priorities in the field of using insects as foods and their components are examined. At present, entomophagy is practiced in Africa, South America and Asia. It is shown that the growing world population, which is increasingly limited in resources upon the rising demand for animal protein, has stimulated the interest to new food sources that can include insects as future alternative sources of animal protein. In the forming global model based on the growing share of renewable energy sources, entomophagy fits in as a renewable source of food energy. Over the last decade, the potential of edible insects as a new ingredient has been studied. It is noted that edible insects can be produced with less environmental impact compared to cattle. Insects have a huge potential at all life cycle stages as a source of nutritional and active substances and are a rich source of animal protein, contain essential amino acids, minerals ( $\mathrm{K}, \mathrm{Na}, \mathrm{Ca}, \mathrm{Cu}, \mathrm{Fe}, \mathrm{Zn}, \mathrm{Mn}$ and $\mathrm{P}$ ), vitamins (B-group, $A, D, E, K$ and $\mathrm{C})$ and unsaturated fatty acids. Assimilability of insect protein is 76-98\%. Insect carbohydrates are represented mainly by chitin contained in a range from $2.7 \mathrm{mg}$ to $49.8 \mathrm{mg} / \mathrm{kg}$ of fresh matter. There are data that different insect species can have immune stimulating, sugar reducing, antioxidant and anti-genotoxic activities, as well as the positive effect in cardiovascular and nervous disorders. In the western countries, different methods of insect processing were developed. The review summarizes advantages and risks of eating insects and legal practices of their consumption. Possible ways and strategies of stimulating edible insect consumption are analyzed taking into account that the majority of population in western countries reject the idea of eating insects. The review of performed studies notes the necessity to eliminate emotional and psychological barriers on the way of accepting edible insect consumption.
\end{abstract}

\section{Introduction}

According to forecasts, the world population will exceed nine billion people by $2050[1,2,3]$. It is expected that the demand for meat products will increase by more than $75 \%$ in 2050 compared to the present level. The growth in per capita meat consumption will be greater in developing countries (from $28 \mathrm{~kg}$ in 2005/2007 to $42 \mathrm{~kg}$ in 2050) than in developed countries (from 80 to $91 \mathrm{~kg}$ ). At present, developing countries mainly account for this increase in demand $(113 \%)$, while it is less in developed ones (27\%). It is estimated that the growth in meat consumption will be more than $150 \%$ in several world regions from 2010 to 2050 . For example, it will be $187 \%$ in Middle East and North Africa, $202 \%$ in Sub-Saharan Africa and 272\% in South Asia $[4,5]$.

Developed countries have higher per capita protein consumption than developing countries (about $96 \mathrm{~g} /$ capita/day); however, a significant proportion (65\%) of this amount is meat. On the contrary, protein consumption in developing countries is significantly lower (about $56 \mathrm{~g} / \mathrm{capita} /$ day) and animal protein accounts only for $15 \%$. With that, animal husbandry, including production of forage crops, occupies about $70 \%$ of world agricultural lands (or 30\% of Earth's land surface) and uses 77 million tons of plant or animal protein to produce only 58 million tons of protein for human consumption annually [6].

The growth in the global demand for meat and scarcity of land resources stimulate searching for alternative protein sources $[4,7]$.
This will require an almost twofold increase in food output using existing agroecosystems taking into consideration the fact that global warming is gradually reducing areas used for food production worldwide [8]. The climate change, enhancement of the technogenic impact on the environment, agricultural areas, water resources, forests, fish supply and biodiversity as a result of the industrial development also negatively influence the food sector $[7,9]$. With that, it is noted that limitation of the amount of agricultural land causes the necessity to search for an alternative to meat and meat products with regard to the fact that animal husbandry is one of the leading causes of the anthropogenic climate change as it is one of the main sources of greenhouse gas emissions. Therefore, sustainable diets with reduced amount of meat or the use of alternative protein sources are needed. Insects are this alternative and can be regarded as available food for humans or feed for livestock $[1,10,11,12,13]$.

Insects are accepted as animal food in many Asian, African, Oceanian and Latin American countries, where insects are historically consumed and used as the main protein source [14] ensuring the sufficient nutritional value for humans. However, the rapid growth in food production due to the technological progress to a large extent excluded insects from the human diet [1].

It is believed that insects emit less greenhouse gases and ammonia than conventional livestock (cattle, pigs and poultry), which potentially make them more environmentally friendly [15]. 
One of the main reasons of expediency of using insects for nutrition is the fact that they have positive ecological properties: they are cold blooded and do not use energy for maintenance of their body temperature contrary to mammalians and birds; therefore, their feed conversion is much more efficient than in conventional livestock [16].

Insects are poikilothermic. In other words, insects spend much less food energy and nutrients than warm blooded livestock. Insects are much more efficient in transformation of phytomass into zoomass (that is, plant biomass into animal biomass) than conventional livestock. Therefore, much more animal protein is produced per kilogram of phytomass consumed by insects than by conventional livestock. Insects are much more fecund and grow much faster. For example, each individual produces thousands of offspring compared to several ones produced by conventional livestock [17].

\section{Use of insects as a food source. Historical aspects}

FAO has considered insects as food since $2003[16,18]$ and encourages consumption of insects (entomophagy) in the Western world due to a possibility of sustainable food production.

Entomophagy plays an important role in assurance of food security and improvement of living conditions in many world nations. Eating insects is a part of the common diet like meat or fish consumption for about 2.5 billion people, mainly in Africa, Asia and Latin America. Insects are eaten in 29 Asian, 36 African and 23 American countries. In some places, they are considered a delicacy, while in others, they are the main diet. Insects represent high quality food for humans and animals, and according to various data, 1600-2100 insect species are consumed worldwide $[7,11,19]$.

Entomophagy can be regarded as potentially more sustainable source of animal protein than red and white meat, on which food security depends now in the most parts of the world. In the currently forming global model based on the growing share of renewable energy sources, entomophagy fits in as a future renewable source of food energy [17].

In ancient times, eating insects was quite a common event. In the first century $\mathrm{AD}$, Roman historian Pliny the Elder described cossus, which is the larva of the longhorn beetle. Li Shizhen wrote a comprehensive book about Chinese medicine and food during the Ming Dynasty in China, which included many insects $[17,19]$.

With appearance of organized religions, the number of people avoiding entomophagy began to increase as in several religions, the followers are recommended to eat only certain types of red or white meat (which completely exclude insects), while in some other religions, consumption of any form of animal protein is not recommended to prevent animal sacrifice [17].

In 1737 in France, René Antoine Ferchault de Réaumur indicated the inconsistency of the fact that frogs, snakes, and lizards were eaten across France, but entomophagy caused disgust [19].

In 1885 in England, Vincent Holt wrote "Why not eat insects?". He stated that "it is hard... to overcome the feelings that have been instilled into us from our youth" and that "the general abhorrence of insects seems almost to have increased of late years, rather than diminished, owing, no doubt, to the fact of their being no longer familiar as medicines." A growing taboo from childhood is described but he goes further, "there is not such a very strong prejudice among the poorer classes against the swallowing of insects" and "there cannot be said to be any really strong objection, among the upper classes, to making any new departure in the direction of foods, if it once becomes the fashion to do so" [19].

Nowadays, several countries continue using insects as common food resources.

Over hundreds of years, national cultures in Asia, South America, Africa and Europe included consumption of different insect species [20]. For example, a survey of markets in Bangkok, Thailand, revealed 164 insect species sold for consumption as food. The most commonly eaten insects are beetles, caterpillars, bees, ants, crickets, grasshoppers and locusts. In Zimbabwe, Zambia, and Nigeria, edible insects are usually sold in school cafeterias and open markets. Some insects are appreciated for their sensory characteristics and are consumed in high-class restaurants. For example, escamoles (ant eggs) are considered a delicate gourmet dish in Mexico, Laos, Cambodia, and Europe [21].

Entomophagy has been in existence in China for more than 2000 years; presumably, about 324 species from 11 orders are eaten there. India has many developed ways of using insects, including production of silk, fertilizers, food and medicines. Approximately 255 insect species are used as food depending on seasonal or regional differences in culture. In Thailand, insects are an important source of protein, fat and other nutrients and more than 80 species are considered edible food resources. Moreover, Thailand's Ministry of Public Health recommends rural communities to eat insects to intake necessary nutrients [1].

Sago grub (Rhynchophorus ferrugineus) is a popular edible insect in Papua New Guinea and the main part of the annual grub festival. Locusts, crickets, mole-crickets, mantises, and even spiders are consumed in local regions. Aboriginal tribes ate a wide variety of insects from Cossidae, Noctuidae, Cerambycide, and bees. In Australia, entomophagy is low among European-derived populations, but the market of edible insects has sharply grown along with an interest in bushfood and insects are now available in restaurant menus [1].

In Mexico, edible insects are traditionally consumed both in rural and urban areas. However, the growing westernization of cities after Spanish conquest finally limited entomophagy mainly to rural regions [22]. Nevertheless, escamol, a dish from insects fried with aromatic spices, is often served in Mexican restaurants. Edible insects are the 
main protein source for Amazonian tribes in Brasil, in particular, Rhynchophorus palmarum and Atta ants are quite popular. In Colombia, the Yukpa people prefer insects to meat; however, they had to reduce insect consumption due to massive deforestation [1].

Summarizing, it can be said that appearance of insects as a viable food group can be explained by their nutritional, ecological and economic value. An increased attention to edible insects is a part of the multifaceted strategy for achieving global food security [1].

It is expected that the global edible insect market will exceed 522 million U.S. dollars by 2023 [23] and according to Bloomberg, it will be $1,181.6$ million U.S. dollars (Figure 1).

\section{Nutritional value of insects}

Despite existence of many edible insects in the world and active consumption of insects by the population in many countries, available data on the nutrient composition of insects are still insufficient $[24,25]$. The nutrition value of insects can be influenced by a particular species, the development stage (for example, T. molitor larvae are a source of calcium, zinc and magnesium; pupae are a source of only magnesium; and adult individuals are a source of iron, iodine, magnesium and zinc), location, season, feed and other factors [25].

Insects as food are usually regarded as a healthy, nutritional alternative to conventional meat products such as chicken, pork and beef. They are rich in protein (in general, from 40 to $70 \%$ on a dry weight basis), minerals (calcium, iron and zinc) [26] and vitamins; their essential amino acid content is similar to beef and soybean; the unsaturated acid content is $10-30 \%$ of dry matter $[12,13,27]$.
Novak et al. [25] analyzed the composition of 236 out of more than 2000 edible insect species and showed that insects are usually rich in protein, fat and minerals, but poor in carbohydrates excluding fiber [27]. The average protein content on a dry matter basis is in a range from $34.35 \%$ in termites (Isoptera) to $61.32 \%$ in grasshoppers, crickets and locusts (Orthoptera), the fat content is in a range from $13.41 \%$ in Orthoptera to $33.40 \%$ in beetles and grubs ( $\mathrm{Co}$ leoptera), the fiber content is in a range from $5.06 \%$ in termites to $13.56 \%$ in true bugs (Hemiptera), the nitrogen-free extract is between $4.63 \%$ in dragonflies and damselflies (Odonata) and $22.84 \%$ in termites, and the ash content is in a range from $2.94 \%$ in cockroaches (Blattodea) to $10.31 \%$ in flies (Diptera) [28].

As a rule, the predominant amino acids in insect protein are phenylalanine, tyrosine, leucine and valine, while methionine, cysteine and tryptophan were less abundant [28].

The amino acid content in insect protein, in general, corresponds to WHO recommendations. All species of edible insects contain a sufficient amount of isoleucine, leucine, lysine, phenylalanine, threonine, valine, arginine, histidine and tyrosine. As a rule, the highest amount of lysine, valine, methionine, arginine and tyrosine is in Blattodea compared to other insects. The amount of leucine in Coleoptera is higher than that in other animal protein sources including livestock. Likewise, the amount of phenylalanine in Hemiptera is usually higher than that in all other known protein sources. Insects at the stage of nymphs (an immature stage of arthropods with incomplete metamorphosis (ticks, Apterygota, some Pterygota)) are usually the most abundant source of almost all amino acids. They are especially rich in arginine which improves the condition of heart and blood vessels and strengthens the immune sys-

\section{MARKET OF EDIBLE INSECTS (\$ MILLION)}

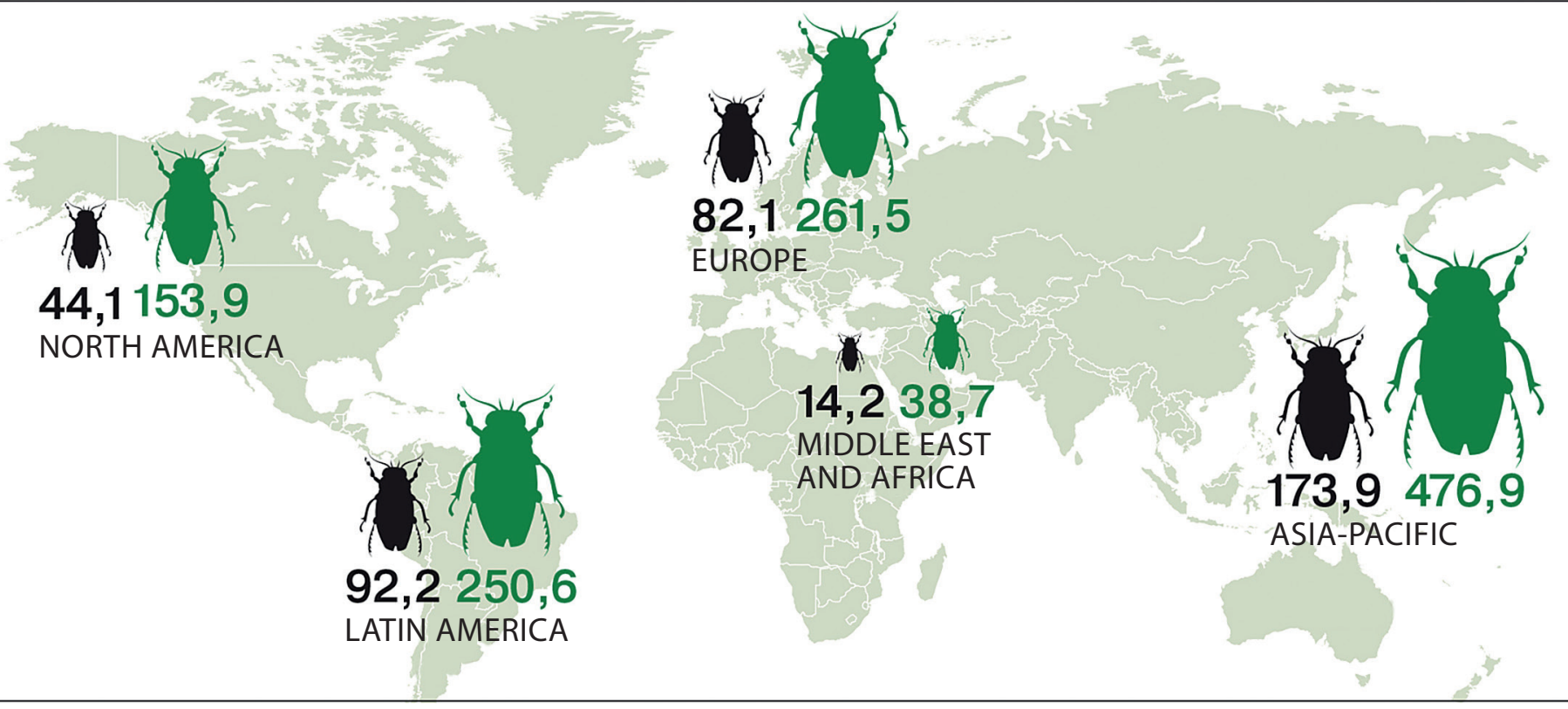

Figure 1. Edible insect market according to Bloomberg 
tem. The amount of arginine is more than twice as high in nymphs of cockroaches (Blatta lateralis) as in beef and pork [29].

Edible insect proteins correspond to the WHO requirements for the essential amino acid content [28]. Moreover, insect proteins, on average, are more digestible (76-98\%) than plant proteins such as peanuts and lentils $(52 \%)$, and only a little less digestible than animal proteins such as beef and egg white (100\%) [12].

The average fat content in insects ranges from $10 \%$ to $60 \%$ of dry matter; with that, the larval stages have higher fat content than adult ones [28, 30], although these values depend on an insect type and their diet. For example, caterpillars and termites have the highest fat level (from 8.6 to $15.2 \mathrm{~g}$ per $100 \mathrm{~g}$ of insects), while the fat content in grasshoppers and crickets is lower (from $3.8 \mathrm{~g}$ to $5.3 \mathrm{~g}$ per 100 $\mathrm{g}$ of insects). The lipid fraction of edible insects is rich in mono- (MUFAs) and polyunsaturated fatty acids (PUFAs) with the high content of $\omega-3$ and $\omega-6$ fatty acids [27]. The main MUFAs in edible insects include palmitoleic (C16:1) and oleic acids (C18:1n9). The content of palmitic acid is also relatively high. The total content of polyunsaturated fatty acids may be up to $70 \%$ of total fatty acids $[28,30]$.

The fat content in Lepidopteran and Heteropteran larvae is higher than in other edible insects. Larvae are a rich source of fatty acids compared to insects at other development stages. The adults are the best source of polyunsaturated fatty acids (PUFAs) compared to pork, beef and insects at other stages. Linoleic acid is the main PUFA in insects. Butterflies and moths (Lepidotera) having high amounts of PUFAs are especially rich in a-linolenic acid, which was identified as a potential nutraceutical for brain protection against stroke [29].

The results of several studies showed that certain insect species had the high content of omega- 6 fats and omega-6: omega-3 ratio in a range from 27 to 17 , which is higher than the $\mathrm{FAO} / \mathrm{WHO}$ recommendations. Another research of insect lipids revealed that the total lipid content in insects varied widely from $24 \%$ in cicadas to $0.3 \%$ in June beetles [19].

Insect carbohydrates are largely represented by chitin, which content ranged from $2.7 \mathrm{mg}$ to $49.8 \mathrm{mg} / \mathrm{kg}$ of fresh matter. Some species of edible insects contain acceptable amount of minerals ( $\mathrm{K}, \mathrm{Na}, \mathrm{Ca}, \mathrm{Cu}, \mathrm{Fe}, \mathrm{Zn}, \mathrm{Mn}$ and $\mathrm{P}$ ), as well as vitamins such as B-group vitamins, vitamins A D, $\mathrm{E}, \mathrm{K}$ and $\mathrm{C}[30]$.

Caterpillars are especially rich in vitamins B1, B2 and B6 [28]. Bee pupae are a source of vitamins A and D, while red palm weevil (Rhynchophorus ferrugineus) is a source of vitamin $\mathrm{E}$ [29]. A wide range of micronutrients can be found in edible insects, including iron, magnesium, manganese, phosphorous, potassium, selenium, sodium and zinc [28].

The mineral content in various insects is significantly different. The majority of insects contain only a low amount of calcium (less than $100 \mathrm{mg} / \mathrm{g}$ on dry matter ba- sis); however, horse fly larvae and adults of melon bugs are rich in it. Pupae of Polybia occidentalis can provide only 54 mg of potassium per $100 \mathrm{~g}$, while Apis mellifera, which also belongs to Hymenoptera, has the high potassium content at all development stages, for example, $1500 \mathrm{mg}$ of potassium per $100 \mathrm{~g}$ of mature individual. Macrotermes nigeriensis contains only $6.1 \mathrm{mg}$ of magnesium per $100 \mathrm{~g}$, while Euschistus egglestoni provides $1910 \mathrm{mg}$ of that substance per $100 \mathrm{~g}$.

The majority of edible insects are particularly rich in iron. The iron content in insects is usually higher than in fresh beef.

The energy efficiency of different insect species has similar and quite high values compared to conventional meat products but depends on their fatness [31].

At the same time, edible insects have the high value in providing calories, which content ranges from 290 to more than $750 \mathrm{kcal} / 100 \mathrm{~g}$ of dry matter [31].

Ramos-Elorduy and Pino [32] calculated energy indicators of 94 insect species used as food and found that among species analyzed, $50 \%$ had higher caloricity than soybeans; $87 \%$ exceeded corn, $63 \%$ were superior to beef and $70 \%$ were better than fish, lentils and beans.

Coleopteran and Lepidopteran species give significant energy. For example, energy values in meat from farm animals are $165-705 \mathrm{kcal} / 100 \mathrm{~g}$, in vegetables and potato $308-352 \mathrm{kcal} / 100 \mathrm{~g}$, while edible insects provide 217 $777 \mathrm{kcal} / 100 \mathrm{~g}$, and insects raised on organic waste give $288-575 \mathrm{kcal} / 100 \mathrm{~g}$ [33].

As a rule, adult insects contain a high amount of chitin, which is indigestible, and therefore, have the low calorie content. Larvae and pupae usually contain high amounts of proteins and fats, which correspond to high calories. Therefore, products made from insects of different stages can fit people with different needs [29].

Carbohydrates in insects mainly exist in two forms: chitin and glycogen. The first one is a polymer of $\mathrm{N}$-acetyl$\mathrm{D}$-glucosamine, which is the main component of the exoskeleton [16], while the latter is a source of energy stored in cells and muscle tissues. The mean carbohydrate content in edible insects ranges from $6.71 \%$ in stink bug to $15.98 \%$ in cicada [34].

An effect on changes in functional properties of meat products when adding components from insects practically was not studied. For example, it was found that when replacing $10 \%$ of lean pork in emulsion sausages with Tenebio molitor or Bombyx mori flour, emulsion sausages had the high added value but the consistency of such sausage was harder regardless of the initial processing and the sausage had lower moisture content compared to the control sausage sample [12].

\section{The use of insects in medicine}

Discovery of physiologically important substances contained in edible insects makes their medicinal use a potentially important practical direction. However, taking into 
account that comprehensive scientific data are absent up to now, further research is necessary to verify benefits of using insects as healthy food or medicines [1].

There are several data indicating that termites (Macrotermes annandalei) can have immune stimulating activity. Another insect that historically has been considered beneficial for health is silkworm (Bombyx mori L.). Studies revealed a glucose reducing agent in its blood, which led to the development of silkworm powder as an antidiabetic medicine in Korea [1].

The crude extract of mulberry silkworm was effectively used in cardiovascular and nervous disorders as it has a significant effect on hypercholesterolemia and atherosclerosis, possibly, due to its antioxidant and hypolipidemic effect [35].

The methanol extract $(1 \mathrm{mg} / \mathrm{ml})$ of muga silkworm (Antheraea assamensis Helfer) pupae with the high content of phenolic acid (11.2 mg catechin/g) and flavonoid (5.12 mg quercetin/g) shows the antioxidant and anti-genotoxic activites and provides protection against $\mathrm{H} 2 \mathrm{O} 2$-induced DNA damage. The main functional component of the mulberry silkworm extract powder is the alpha-glucosidase inhibitor, which has the blood sugar-lowering effect and a potential in hyperglycemia inhibition in patients with diabetes [36].

Antimicrobial peptides, which are the key elements of the innate immune defense against bacterial and fungal infections, were isolated from insects. The insect metalloproteinase inhibitor and antimicrobial peptides from the greater wax moth (Galleria mellonella) may serve as promising templates for the rational design of new medicines as there are data that the combination of antibiotics with inhibitors of pathogen-associated proteolytic enzymes has synergistic therapeutic effects [37].

At the turn of the 20th century, the Russian scientist Ilya Ilyich Mechnikov studied and proved a negative effect of preparations from the greater wax moth on Mycobacterium tuberculosis. When studied the historical experience of folk medicine, he presumed that if the greater wax moth larvae could destroy wax, then they could destroy waxy coating of M. tuberculosis. The extract of the greater wax moth larvae negatively influences $M$. tuberculosis at any stage of its development destroying its waxy coating. Specific enzymes of the greater wax moth larvae facilitate resorption of local lesions.

The extract of the greater wax moth larvae is a natural immune modulator and non-steroid anabolic, which enhances body defenses and body resistance against different diseases. The pharmacological and therapeutic action of the Galleria mellonella extract is quite wide. In addition to the negative effects on M. tuberculosis, it has adaptogenic, cardioprotective properties, alleviates myocardial ischemia [38].

Chitin and chitosans of insects are used as immune adjuvants (substances enhancing immunity) and non-allergic drug carriers. In addition, they have the lipid binding function in the human gastrointestinal tract and, therefore, reduce lipid absorption in the intestine. They decrease the level of cholesterol and triglycerides in plasma and improve the HDL/total cholesterol ratio [36].

It is obvious that the above mentioned results as well as other data on the curative effect of insect biologically active compounds require further study to assess the degree of their effectiveness and prove it by clinical trials.

\section{Consumer attitude to entomophagy}

Modern models of edible insect consumption

With the agriculture development and livestock domestication, the habits of insect eating disappeared in many regions. As cultural customs changed, insects turned from the main food source into snacks, unusual food ingredients and in several cases, they are consumed as delicacies, for example:

- wasps, bamboo caterpillars, crickets, and locusts are sold as delicacies in the best restaurants and food shops in Thailand.

- annual sales of edible ants in China reach $\$ 100$ million.

- the rice-field grasshopper, called inago, is a luxury food item in Japan similarly to canned wasps, a $65 \mathrm{~g}$ can of which is sold for more than $\$ 10$. Even more expensive are hornets, which are sold at a price of more than $\$ 20$ for $100 \mathrm{~g}$.

- there is a sharp growth in tourist interest regarding the native Australian "bush tucker" foods, which include insects such as wichety grubs (Cossidae), bogong moth, and bardee larva.

- in Mexico, high-end restaurants charge more than \$25 per plate of escamoles (pupae of an ant species) and gusanos (butterfly larvae). When exported, escamoles have a fantastic price of $\$ 50$ for a $30 \mathrm{~g}$ can (almost two dollar per gram). Escamoles is a national Mexican dish, which is a corn tortilla with unusual filling that on taste resembles a mixture of butter and nuts. The filling is specifically processed larvae and pupae of black ants belonging to the genus Liometopum, which lay eggs in the agave roots in Mexico.

An attitude of the Western society and ways

of overcoming the consumer negative perception

of entomophagy

In the Western culture, eating insects is taboo as the majority of the population consider them disgusting and their eating unacceptable. The persisting negative perception of insects prevents extension of the global market and limits insects as the main nutrition option, which can be linked with the fact that people are skeptical about novel products due to general neophobic trends [20]. Therefore, many consumers regard insects as a source of fear or disgust, have strong aversion to insects as normal food in their diet and fully neglect their high nutritional value [9].

Western consumers are reluctant to eat whole insects and, therefore, insect-based food ingredients included in the composition of other products can be alternative ingredients [13]. In addition, fats, chitin, minerals and vitamins 
can be extracted from them. The insect gelatin could be used to replace animal gelatin as insects are not associated with Bovine Spongiform Encephalopathy (BSE) and could be an acceptable Halal product.

Hypothesis trying to explain the Western beliefs are varied from psychological associations between insects and diseases, death, dirtiness [36] and food contamination to neophobia. An effect of Western taboo is such that the consumer perception is the main obstacle for the entomophagy development in Western cultures [19].

Nevertheless, insects still enter the human stomach. It is estimated that a person eats up to $0.5 \mathrm{~kg}$ of insects during the whole life. We eat mealworms with bread, worms and larvae enter the stomach with jams and tomato paste.

An example of entomophagy in the West is the Italian island of Sardinia, where cheese casu marzu notable for containing live larvae of cheese fly is produced. Casu marzu means 'rotten cheese' in Sardinian language; the term 'maggot cheese' is also used in spoken language. Casu marzu is made from another Sardinian cheese - pecorino. Casu marzu is hold longer than the typical fermentation stage bringing it to the state of decomposition caused by the digestive action of the larvae. The larvae accelerate the breakdown of cheese fats making the product soft. Also, some liquid called lagrima ('teardrop') comes out of the cheese. The cheese is considered edible only when maggots are alive. Due to the health hazard and because 'rotten cheese' is considered a contaminated product its selling was officially forbidden in Italy. However, in 2010, casu marzu was recognized as the cultural heritage of Sardinia and again permitted [40].

An example of indirect entomophagy is the carmine dye obtained from carminic acid produced by female cochineal insects (Dactylopius coccus). Cochineal produces carminic acid in an amount of $17-24 \%$ of body weight. Carmine historically has been used as a dye for textile, and also found its use in production of cosmetics and some food products such as processed meats, canned foods, alcoholic beverages, yogurt and bakery products as a replacement for beet. Carmine is registered as food additive E120 $[1,19]$.

The use of lac insects (Kerria lacca) is similar. They are cultivated for production of shellac. The pigment is originally bright red, but can be from violet to red and brown. It is mainly used for dying textile fibers and in cosmetology, but today it is also used in beverage production [29].

However, as was mentioned above, many other cultures include insects as a daily part of their diets, in which insect consumption is not weird. Payne et al. [24] indicate that since the majority of studies on insect acceptance as a food product/ingredient have been carried out in cultures not eating insects, their results show only hypothetical involvement in their consumption.

The consumer perception of food with insects was studied by test food, a vegetable soup with bee larvae included as a visible or non-visible ingredient. It was shown that different soup versions were acceptable from a consumers' point of view; but the soup that contained nonvisible bee larvae was accepted to a higher degree than the soups with visible larvae. The results correspond to another study showing that the use of insects in food can be regarded as slightly positive. The results showed that use of 'insect flour' with non-visible insects had higher acceptance than the use of whole and visible insects as food or a food ingredient. Moreover, results from the focus group study showed that consumers preferred food products and dishes with milled or non-visible insects over foods with whole or visible insects [13].

Up to now, the systematic studies of the attitude to insects as food were mainly concentrated on populations not eating insects and had ambiguous results [24]. For example, the preliminary survey of 53 students from the University of Southampton (Southampton, UK) showed that $51 \%$ "would not taste" insects mainly due to perception of insect food as "disgusting" and "with bad taste".

Nowadays, edible insect consumption is minimal in developed countries, but people's curiosity is growing. In Europe, edible insects cause different emotions and at the same time huge curiosity. Novel food, especially with insects, can cause anxiety and a sense of insecurity due to ignorance, lack of knowledge and experience in dealing with it. As a result, internal conflicts and barriers linked with eating new unknown food arise. Novel food can cause ambivalent attitudes with components of both positive and negative approaches. Therefore, consumers' prejudice based on visual aspects and their willingness to expand their knowledge about nutrition are contradictory regarding this food [41].

People will accept insect food if it will look and smell familiar and if insects are not served intact. The research carried out in the Universita degli Studi Napoli Frederico II showed that three characteristics increase the consumers' willingness to buy foods from insects: a decrease in the number of insects in meal, addition of the flavoring agent cocoa and organic certification [24].

It is noteworthy that mass media in countries where the tradition of eating insects is absent are prone to present insect food differently as novel, disgusting, healthy and/or ethically preferable compared to meat. Data suggest that this type of information can significantly affect consumer attitudes. The research group from the University of $\mathrm{Na}$ poli Federico II (Napoli, NA, Italy) surveyed consumers in two European countries, Denmark and Italy (282 University students) and found that an effect of communication exceeded other factors such as age, gender and nationality influencing a consumer attitude. In the research, information about social benefits was of great influence; data were obtained during investigation of benefits for humans [42]. Therefore, information about social benefits can be a useful marketing strategy; although, taking into consideration the absence of reliable knowledge about consequences of increasing insect consumption, it is, likely, irresponsible. 
Finally, product characteristics are also a decisive factor in acceptance formation.

For example, to assess acceptance of the trend towards eating insects promoted by the FAO diet, acceptability of novel edible insect products with mealworms Tenebrio molitor L. and house crickets Acheta domesticus L. was analyzed among young Polish consumers (101 students; 74 females and 27 males). These products were prepared in the form of four different oatmeal bars: one without insects, one with whole mealworms, one with ground mealworms and one with ground crickets [41].

According to the consumers' opinion, the bars contained whole mealworms were the worst. Moreover, the main problems with acceptance of the product with insects were caused by the color of ground crickets and visible whole pieces of the insects in the edible bars. The study proved that the acceptance of insect bars as food depended on their taste and smell. The acceptance rate for the basic bar was the highest, while the bar with whole mealworms had the lowest acceptance rate. It is necessary to note that a predictor (the smell of the presented bars) was a significant statistical indicator of quality in three out of four cases studied.

Inclusion of edible insects into already known foods can be most acceptable for the insectophobic culture compared to providing insects directly as a food variant, and the use of insects as food ingredients will positively affect formation of sustainable business models [23].

The study performed in the University of Parma (Italy) was aimed at studying the main reasons of the negative perception of insects as food and stimulating consumption of edible insects in the future. It was carried out on the mixed group of Italian individuals $(\mathrm{n}=46)$ with different age and gender. The participants tasted three species of edible insects (cricket, honeycomb moth and grasshopper), and then they were given a questionnaire to reveal their opinions about entomophagy. Analysis of the results shows that curiosity and environmental benefits are the most important factors in motivating insect consumption in the future. However, the majority of respondents stated that entomophagy would not be approved and supported by their family and/ or friends. At present, it is difficult to predict whether edible insects will become the "food of the future" [43].

To increase consumer interest in the Western countries, several methods for insect processing were developed. These methods include:

- drying (for example, sun drying, freeze drying, oven drying, microwave drying); extraction by ultrasound, cold atmospheric pressure plasma processing or dry fractionation;

- fractionation mainly aimed toward using insects as ingredients in an unrecognizable form, such as powders or meal $[30,44,45]$.

All abovementioned methods can affect sensory properties of edible insects. Aroma and taste are quite different. For example, taste of ants and termites is described by sensory descriptors such as sweet, nutty, fatty, crunchy, notes of cereal and wood; taste of grasshoppers as aroma of cereal, wood and nuttiness, flavor of umami and vegetable, crusty, hard; taste of crickets as popcorn, chicken, creamy, aroma of broth, nuttiness and cereal, flavor of umami and vegetable [46].

Taste and aroma are mainly influenced by pheromones present on the surface of the insect body that depend on the environment, as well as forage and/or methods of processing. For example, scalded insects are practically tasteless, because pheromones are washed off [45]. Moreover, insects take the flavor in added ingredients during cooking [30].

Analysis of new insect product spreading (by the number of records) obtained by BUGSfeed - a website, which is engaged in communication and promotion of entomophagy, shows that the most consumed are crickets (150 records), mealworms (58), grasshoppers (43), ants (28) and silkworms (22). Food products that are the best form for persuading consumers to try novel products are protein bars (41), snacks (37), cookies (25) and sweets (18).

Despite multiple advantages of eating insects, the future of insect industry is unfavorable in Western societies [9] taking into account the fact that existing cultural aversion cannot be changed quickly [47].

To increase consumer acceptability, a special attention should be given to social, practical and contextual factors influencing food consumption. These efforts include continuous education and propaganda of the relative potential of edible insects to solve ecological, demographic and land problems today and in the future.

\section{Quality, safety and legislation in the sphere of using edible insects}

The main obstacle in the edible insect industry is the absence of systematic work on assurance of product safety and shelf life [9]. The process of insect growing also requires standardization and quality control and this goal requires the development of state legislation and regulatory acts [7].

At present, the use of insects as food in EU falls within the scope of the Regulation (EU) 2015/2283 of 25 November 2015 on novel foods. This document repealed Regulation (EC) No 258/97. As before, producers are required to assess food safety previous to its placing on the market. In this regard, insects are considered novel food products. This means that insects cannot be grown or sold unless each particular species was recognized as safe and approved by the European Commission. According to the Regulation (EU) 2015/2283, the correspondence of novel foods to the requirements should be assessed in details. Assessment and authorization of novel food have been significantly simplified. Previously, this procedure was carried out in each EU member state. Today, ESFA (European Food Safety Authority) will be engaged in this activity. ESFA published the guiding principles regarding required documentation for submission of an application for of- 
ficial authorization according to the present Regulation. This needs authorization based on risk assessment for a particular use (at a product level), for example: insect meal for use in bread, pasta and snacks, insect protein for use in cocktails, processed meat products and so on.

Food safety is of special importance with regard to new food sources. In the context of edible insects, there are four ways of food safety risk emergence: 1) an insect itself can be toxic; (2) an insect can acquire toxic substances or human pathogens from the environment during its life cycle; (3) an insect can become spoiled after harvest; (4) consumers can have an allergic reaction to an insect [9].

Edible insects are food products of animal origin and usually are eaten as a whole, including the digestive tract. This means that they may contain biological agents with the hazardous potential (for example, bacteria, parasites, viruses, prions, yeasts, molds, mycotoxins, histamine, and antibiotic resistance genes). Therefore, the use of insects as food sources can present a potential hazard regarding pathogen transfer and their safety should be thoroughly controlled [48].

Moreover, the intestinal content of insects can be an important part of their use as a food source as the total biomass content from intestinal microbiota can be $1-10 \%$ to the insect body weight and it is quite difficult to remove the intestinal part from edible insects. Moreover, allergic reactions can occur as several edible insects have cross-reactive allergic proteins. Carmine produced from the bodies of female cochineal insects and used as a food dye can cause an allergic reaction in some patients. Taking into account that few studies of allergic reactions to edible insects were carried out, it is necessary to pay attention to unknown potential allergens contained in edible insects. Insects like other food products can cause allergic symptoms even after the first contact. For example, silkworm pupae, which are a rich source of protein and amino acids for humans, are well known for their allergenicity as their eating leads to anaphylactic reactions in more than 1000 patients in China every year. It has been suggested that people suffering from shrimp allergy can also be allergic to other mollusks and arthropods such as cockroaches, grasshoppers, fruit flies and other edible insects $[19,49]$.

To ensure safe use of edible insects as feed and food resources, it is necessary to study hazardous substances, including insect allergens and toxicants as well as their impact on the development of the pathological symptoms in the human body.

For example, acceptability of three flours for porridges used as complementary foods based on "Winfood Classic" (corn and amaranth fortified with edible termites and small fish) and "Winfood Lite" (multi-micronutrient complementary food fortified with maize and amaranth) compared to corn soy blend plus (CSB+) was assessed among 57 Kenyan infants at the age from six months to 24 months. The results of the study on the frequency of adverse health outcomes such as diarrhea, vomiting, stomach ache, skin rashes and difficult breathing before, during and after the acceptability study did not show adverse health consequences for any of the foods including the "Winfood Classic" containing termites. The revealed cases of adverse health outcomes (9.3 per cent), vomiting in the group of children received the corn soy blend plus, were below the 10 per cent threshold required to state that a product has adverse effects [49].

Although insects actually transfer pathogenic bacteria, they are often not pathogenic to humans and, therefore, many pathogenic bacterial hazards to humans originate from rearing, processing and preservation of insects. Nevertheless, it was found that farmed insects had high levels of aerobic and anaerobic bacteria. Insects may be carriers of both Campylobacter and Salmonella. They may also transfer viruses and have the potential for mycotoxigenic fungal growth, although this is not hazardous to humans upon proper processing and storage. With this, the European Food Safety Authority established that edible insects are unlikely to be of significant safety risk [19]. Edible insects were also studied as carriers of bacteria with transferrable antibiotic resistance genes, and a high frequency of the tetracycline resistance genes was found despite a high variability among samples. It is suggested that these genes may be transferred to human microbiomes because of consuming such insects [48].

The European Food Safety Authority is of the opinion that properly grown insects may be safe with regard to allergenicity and environmental hazards as well as both chemical and biological potential hazards, because their microbiological hazard is comparable to non-processed food of animal origin [50].

\section{Use of edible insects in Russia}

In Russia, the question of using insects for human nutrition has not been raised up to now. Few projects on insect growing existing in the country deal with processing waste from animal husbandry by insects and production of animal feed based on insect biomass ${ }^{1}$.

Entoprotech (Moscow) founded in 2015 grows black soldier fly and specializes in processing agricultural waste into feed additives for animals.

Daily output is about $700 \mathrm{~kg}$ of concentrated flour from black soldier fly with the protein content of up to $62 \%$. The flour is in demand among animal husbandry enterprises. Also, the company sells whole dry larvae of black soldier fly: some customers need the product in this form (for example, for the Moscow zoo), others process them by themselves for their needs.

ZooProtein (Lipetsk region) is engaged in recycling waste from animal husbandry enterprises into protein feeds and fertilizer using maggots of fly Lucilia Caesar. The company has been working since 2016 and initially special-

\footnotetext{
${ }^{1}$ Karabut T. Protein of the 21 century: crickets, cockroaches and fly larvae. The market of edible insects reached $\$ 400$ million and will develop with the record rate // Agroinvestor, № 06, June 2019. Retrieved from https://www. agroinvestor.ru/technologies/article/31853-protein-xxi-veka/ Accessed January 20,2021
} 
ized in growing fishing maggots. Then, they understood the prospects of protein feed production and switched to flies. The company can produce up to $500 \mathrm{~kg}$ of protein feeds in a month. Their product is in great demand among poultry farms, animal husbandry enterprises and fish farms.

For InAgroBio (Yaroslavl region), which specializes in aquaculture, production of the housefly (Musca domestica) is more like the secondary activity. This is how the enterprise provides its juvenile fish with feed. The enterprise processes larvae by a special method without drying. At first, necessary biologically active substances are isolated from biomass and, then, remained biomass is dried and used for fish feeds.

\section{Conclusion}

It is believed that entomophagy can become a solution to the increasingly urgent global problem of ensuring food security. Several countries have already been using insects as alternative sources of food proteins and feed, as well as with the medical purpose. Available studies confirm the significant nutritional and pharmaceutical value of edible insects. Different strategies were developed to expand the market of edible insects and counteract with existing aversion and hostility of western consumers towards entomophagy. The modern state of technologies for edible insects is still insufficient for replacing traditional animal food worldwide; although, edible insects have a huge potential to be the main source of nutrients.

However, to use insects by people and domestic animals, as well as for other purposes, further research is necessary to confirm their consumer acceptability, sustainability and safety for health. These questions are and will be a subject of research for many scientists from different fields.

\section{REFERENCES}

1. Kim, T.-K., Yong, H.I., Kim, Y.-B., Kim, H.-W., Choi, Y.-S. (2019). Edible Insects as a Protein Source: A Review of Public Perception, Processing Technology, and Research Trends. Food Science of Animal Resources, 39(4), 521-540. https://doi.org/10.5851/ kosfa.2019.e53

2. Grafton, R.Q., Daugbjerg, C., Qureshi, M.E. (2015). Towards food security by 2050. Food Security, 7(2), 179-183. https://doi. org/10.1007/s12571-015-0445-x

3. Jansson, A., Berggren, A. (2015). Insects as Food - Something for the Future? A report from Future Agriculture. Uppsala, Swedish University of Agricultural Sciences (SLU). - 36 p. ISBN: 978-91-576-9335-8

4. Herrero, M., Wirsenius, S., Henderson, B., Rigolot, C., Thornton, P., Havlík, P., de Boer, I., Gerber, P.J. (2015). Livestock and the environment: what have we learned in the past decade? Annual Review of Environment and Resources, 40(1), 177-202. https://doi.org/10.1146/annurev-environ-031113-093503

5. Van Huis, A. (2015). Edible insects contributing to food security? Agriculture \& Food Security, 4(1), Article number 20. https://doi.org/10.1186/s40066-015-0041-5

6. Pimental, D., Dritschilo, W., Krummel, J., Kutzman, J. (1975). Energy and land constraints in food protein production. Science, 190(4216), 754-761. https://doi.org/10.1126/science.190.4216.754

7. Van Huis, A., Oonincx, D.G.A.B. (2017). The environmental sustainability of insects as food and feed. A review. Agronomy for Sustainable Development, 37(5), 43. https://doi.org/10.1007/ s13593-017-0452-8

8. Belluco, S., Losasso, C., Maggioletti, M., Alonzi, C.C., Paoletti, M.G., Ricci, A. (2013). Edible insects in a food safety and nutritional perspective: A critical review. Comprehensive Reviews in Food Science and Food Safety, 129(3), 296-313. https://doi. org/10.1111/1541-4337.12014

9. Van Huis, A. (2016). Edible insects are the future? Proceedings of the Nutrition Society, 75(3), 294-305. https://doi. org/10.1017/S0029665116000069

10. Patel, S., Suleria, H.A.R., Rauf, A. (2019). Edible insects as innovative foods: Nutritional and functional assessments. Trends in Food Science and Technology, 86, 352-359. https://doi. org/10.1016/j.tifs.2019.02.033

11. Assielou, B., Due, E.A., Koff, M.D., Dabonne, S., Kouame, P.L. (2015). Oryctes owariensis Larvae as Good Alternative Protein Source: Nutritional and Functional Properties. Annual Research \& Review in Biology, 8(3), 1-9.

12. Gravel, A., Doyen, A. (2020). The use of edible insect proteins in food: Challenges and issues related to their functional properties. Innovative Food Science and Emerging Technologies, 59, Article 102272. https://doi.org/10.1016/j.ifset.2019.102272

13. Berg, J., Wendin, K., Langton, M., Josell, A., Davidsson, F. (2017). State of the Art Report: Insects as Food and Feed. Annals of experimental Biology, 5(2), 37-46.

14. Murefu, T.R., Macheka, L., Musundire, R., Manditsera, F.A. (2019). Safety of wild harvested and reared edible insects: A re- view. Food Control, 101, 209-224. https://doi.org/10.1016/j. foodcont.2019.03.003

15. Oonincx, D.G.A.B., van Itterbeeck, J., Heetkamp, M.J.W., van den Brand, H., van Loon, J.J.A., van Huis, A. (2010). An exploration on greenhouse gas and ammonia production by insect species suitable for animal or human consumption. PLoS One, 5(12), Article e14445. https://doi.org/10.1371/journal.pone.0014445 16. Van Huis, A. (2013). Potential of insects as food and feed in assuring food security. Annual Review of Entomology, 58(1), 563583. https://doi.org/10.1146/annurev-ento-120811-153704 17. Premalatha, M., Abbasi, T., Abbasi, T., Abbasi, S.A. (2011). Energy-efficient food production to reduce global warming and ecodegradation: The use of edible insects. Renewable and Sustainable Energy Reviews, 15, 4357-4360. https://doi.org/10.1016/j. rser.2011.07.115

18. Van Huis, A., van Itterbeeck, J., Klunder, H., Mertens, E. et al. (2013). Edible insects: future prospects for food and feed security. Rome: Food and Agriculture Organization of the United Nations. - 201 p. ISBN 978-92-5-107595-1

19. Palmer, L. (2016). Edible Insects as a Source of Food Allergens. Dissertations, Theses, \& Student Research in Food Science and Technology. - $162 \mathrm{p}$.

20. Dobermann, D., Swift, J.A., Field, L.M. (2017). Opportunities and hurdles of edible insects for food and feed. Nutrition Bulletin, 42(4), 293-308. https://doi.org/10.1111/nbu.12291

21. Ramos-Elorduy, J., Gonzalez, E.A., Hernandez, A.R., Pino, J.M. (2002). Use of Tenebrio molitor (Coleoptera: Tenebrionidae) to recycle organic wastes and as feed for broiler chickens. Journal of Economic Entomology, 95, 214-220. https://doi. org/10.1603/0022-0493-95.1.214

22. Ramos-Elorduy, J., Pino, J. M., Prado, E. E., Pérez, M. A., Lagunez Otero, J., Ladron de Guevara, O. (1997). Nutritive Value of Edible Insects from the State of Oaxaca, Mexico. Journal of Food Composition and Analysis, 10, 142-157.

23. Han, R., Shin, J.T., Kim, J., Choi, Y.S., Kim, Y.W. (2017). An overview of the South Korean edible insect food industry: Challenges and future pricing/promotion strategies. Entomological Research, 47(3), 141-151. https://doi.org/10.1111/17485967.12230

24. Payne, C.L.R., Scarborough, P., Rayner, M., Nonaka, K. (2016). A systematic review of nutrient composition data available for twelve commercially available edible insects, and comparison with reference values. Trends in Food Science \& Technology, 46, 69-77. https://doi.org/10.1016/j.tifs.2015.10.012

25. Nowak, V., Persijnm D., Rittenschober, D., Charrondiere, R. (2016). Review of food composition data for edible insects. Food Chemistry, 193, 39-46. https://doi.org/10.1016/j.foodchem.2014.10.114

26. Mwangi, M.N., Oonincx, D.G.A.B., Stouten, T., Veenenbos, M., Melse-Boonstra, A., Dicke, M, van Loon, J.J.A. (2018). Insects as sources of iron and zinc in human nutrition. Nutrition Research Reviews, 31(2), 248-255. https://doi.org/10.1017/ S0954422418000094 
27. Zielińska, E., Baraniak, B., Karaś, M., Rybczyńska, K., Jakubczyk, A. (2015). Selected species of edible insects as a source of nutrient composition. Food Research International, 77, 460-466. https://doi.org/10.1016/j.foodres.2015.09.008

28. Rumpold, B.A., Schlüter, O.K. (2013). Nutritional composition and safety aspects of edible insects. Molecular Nutrition and Food Research, 57(5), 802-823. https://doi.org/10.1002/mnfr.201200735

29. Tang, C., Yang, D., Liao, H., Sun, H., Liu, C., Wei, L., Li, F. (2019). Edible insects as a food source: a review. Food Production, Processing and Nutrition, 1(1), 8 https://doi.org/10.1186/ s43014-019-0008-1

30. Kouřimská, I., Adámková, A. (2016). Nutritional and sensory quality of edible insects. NFS Journal, 4, 22-26. https://doi. org/10.1016/j.nfs.2016.07.001

31. Gere, A., Zemel, R., Radványi, D., Moskowitz, H. (2017). Insect Based Foods a Nutritional Point of View. Nutrition and Food Science International Journal, 4(3), 555638. https://doi. org/10.19080/nfsij.2017.04.555638

32. Pino Moreno, J.M., Ganguly, A. (2016). Determination of fatty acid content in some edible insects of Mexico. Journal of Insects as Food and Feed, 2(1), 37-42. https://doi.org/10.3920/ jiff2015.0078

33. Ramos-Elorduy, J. (2008). Energy Supplied by Edible Insects from Mexico and their Nutritional and Ecological Importance. Ecology of Food and Nutrition, 47(3), 280-297. https://doi. org/10.1080/03670240701805074

34. Mlcek, J., Rop, O., Borkovcova, M., Bednarova, M. (2014). A comprehensive look at the possibilities of edible insects as food in Europe-a review. Polish Journal of Food and Nutrition Sciences, 64(3), 147-157. https://doi.org/10.2478/v10222-012-0099-8 35. Ali, M.M., Bharati, A.A.S. (2011). Effect of crude extract of Bombyx mori cocoons in hyperlipidemia and artherosclerosis. Journal of Ayurveda and Integrative Medicine, 2(2), 72-78. https://doi.org/10.4103/0975-9476.82527

36. Gahukar, R.T. (2018). Entomophagy in traditional healthcare practiced by indigenous communities: potential, implications and constraints. International Journal of Basic and Applied Sciences, 7 (4), 55-61. https://doi.org/10.14419/ijbas.v7i4.11434

37. Mlcek, J., Borkovcova, M., Bednarova, M. (2014). Biologically active substances of edible insects and their use in agriculture, veterinary and human medicine - a review. Journal of Central European Agriculture, 15(4), 225-237. https://doi.org/10.5513/ JCEA01/15.4.1533

38. Hill, L., Veli, N., Coote, P.J. (2014). Evaluation of Galleria mellonella larvae for measuring the efficacy and pharmacokinetics of antibiotic therapies against Pseudomonas aeruginosa infection. International Journal of Antimicrobial Agents, 43(3), 254-261. https://doi.org/10.1016/j.ijantimicag.2013.11.001
39. Deroy, O., Reade, B., Spence, C. (2015). The insectivore's dilemma, and how to take the West out of it. Food Quality and Preference, 44, 44-55. https://doi.org/10.1016/j. foodqual.2015.02.007

40. Manunza, L. (2018). Casu marzu: A gastronomic genealogy. Chapter in a book: Edible Insects in Sustainable Food Systems. Halloran, A., Dr., Flore, R., Vantomme, P., Roos, N. Springer International Publishing AG. Pages 139-145. https://doi. org/10.1007/978-3-319-74011-9

41. Bartkowicz, J., Babicz-Zielińska, E. (2020). Acceptance of bars with edible insects by a selected group of students from TriCity, Poland. Czech Journal of Food Sciences, 38(3), 192-197. https://doi.org/10.17221/236/2019-CJFS

42. Verneau, F., La Barbera, F., Kolle, S., Amato, M., Del Giudice, T., Grunert, K. (2016). The effect of communication and implicit associations on consuming insects: an experiment in Denmark and Italy. Appetite, 106, 30-36. https://doi.org/10.1016/j.appet.2016.02.006

43. Sogari, G. (2015). Entomophagy and Italian consumers: An exploratory analysis. Progress in Nutrition, 7(14), 311-316.

44. Melgar-Lalanne, G., Hernández-Álvarez, A.-J., Salinas-Castro, A. (2019). Edible insects processing: Traditional and innovative technologies. Comprehensive Reviews in Food Science and Food Safety, 18(4), 1166-1191. https://doi.org/10.1111/15414337.12463

45. Tobolkova, B. (2019). Edible Insects-the Future of a Healthy Diet? Novel Techniques in Nutrition and Food Science, 4(2), Article 000584. https://doi.org/10.31031/ntnf.2019.04.000584 46. Elhassan, M., Wendin, K., Olsson, V., Langton, M. (2019). Quality aspects of insects as food-nutritional, sensory, and related concepts. Foods, 8(3), 95. https://doi.org/10.3390/ foods 8030095

47. DeFoliart, G.R. (1999). Insects as food: Why the western attitude is important. Annual Review of Entomology, 44(1), 21-50. https://doi.org/10.1146/annurev.ento.44.1.21

48. Milanović, V., Osimani, A. Email Author, Pasquini, M., Aquilanti, L., Garofalo, C., Taccari, M., et al. (2016). Getting insight into the prevalence of antibiotic resistance genes in specimens of marketed edible insects. International Journal of Food Microbiology, 227, 22-28. https://doi.org/10.1016/j.ijfoodmicro.2016.03.018

49. Ayensu, J., Annan, R.A., Edusei, A., Lutterodt, H. (2019). Beyond nutrients, health effects of entomophagy: a systematic review. Nutrition \& Food Science, 49(1), 2-17 https://doi. org/10.1108/nfs-02-2018-0046

50. Rettore, A., Burke, R., Barry-Ryan, C. (2016). Insects: A Protein Revolution for the Western Human Diet. Conference: Dublin Gastronomy Symposium. 2016 - Food and Revolution. Dublin, Ireland.

\section{AUTHOR INFORMATION}

Nataliya A. Gorbunova - candidate of technical sciences, Scientific secretary, V. M. Gorbatov Federal Research Center for Food Systems of Russian Academy of Sciences. 109316, Moscow, Talalikhina str., 26. Tel.: +7-495-676-93-17, E-mail: n.gorbunova@fncps.ru ORCID: http://orcid.org/0000-0003-4249-9316

* corresponding author

Alexander N. Zakharov - candidate of technical sciences, Head of Department editorial and publishing, V. M. Gorbatov Federal Research Center for Food Systems of Russian Academy of Sciences. 109316, Moscow, Talalikhina str., 26. Tel.: +7-495-676-93-51, E-mail: a.zakharov@ fncps.ru

ORCID: https://orcid.org/0000-0003-4630-7983

All authors bear responsibility for the work and presented data.

All authors made an equal contribution to the work.

The authors were equally involved in writing the manuscript and bear the equal responsibility for plagiarism.

The authors declare no conflict of interest.

Received 12.12.2020 Accepted in revised 28.02.2021 Accepted for publication 02.03.2021 